\title{
Analysis of thermal and electrical efficiency of photovol- taic/thermal - PV/T modules operating in moderate climate at microscale
}

\author{
Dorota Chwieduk ${ }^{1, *}$, and Jarosław Bigorajski ${ }^{1}$ \\ ${ }^{1}$ Institute of Heat Engineering, Faculty of Power and Aeronautical Engineering, Warsaw University of Technology, Nowowiejska 21/25, \\ 00-665 Warsaw, Poland
}

\begin{abstract}
The paper presents an application concept for PV/T - Photovoltaic Thermal Technology in moderate climates (such as the Polish climate), at a micro scale, i.e. for a single family house. The paper analyses the operation of a PV/T system applied to Domestic Hot Water - DHW heating and electricity production. A mathematical model of the system operation has been developed. The paper focuses on modeling thermal and electrical efficiency of photovoltaic/thermal - PV/T modules. It also briefly presents the governing equations for the thermal energy balance of a storage tank, where thermal stratification effects take place. Some selected results of the numerical simulation of the PV/T system operation are described. Daily distribution of hourly averaged thermal and electrical efficiency of the PV/T modules without cover and with one glazing are presented. The PV/T systems do not give significant thermal energy output in winter. PV/T modules without glazing do not supply heat at all for three winter months, their highest thermal efficiency is in summer and it can be nearly $15 \%$. In the same period glazed modules have efficiency equal to nearly $24 \%$. However, the unglazed modules can give much more electrical energy in summer than those with glazing, and the electrical efficiency can reach the levels of $11.4 \%$ and $9.4 \%$, respectively. In winter the difference is smaller, i.e. for unglazed the efficiency is $12.2 \%$, and for glazed $11.2 \%$.
\end{abstract}

\section{Introduction}

Utilization of solar energy in buildings has become of great interest to construction companies and developers dealing with innovative technologies, especially nowadays when European buildings should be nearly zero-energy according to the EU Directive on the energy performance of buildings [1]. Building-related solar energy technologies are connected with the architectural and civil engineering concepts, which include the application of solar energy systems. The solar energy systems are usually installed on buildings' roofs, but they can be also incorporated into the envelope of a building, constituting its integral elements. In such a case BIST Building Integrated Solar Thermal - and BIPV - Building Integrated Photovoltaics systems are used in modern lowenergy buildings [2]. A building becomes a complex structure of integrated architectural and energy elements, which include different types of solar passive and active systems.

The active solar systems convert solar radiation into a useful form of energy: thermal or electric using different devices in an active way. The conversion of solar energy takes place on the spot, for self-use by building's occupiers. However, the surface of a building envelope is limited and usually there is not enough area of south façade and south roof to incorporate solar thermal and photovoltaic systems to supply most of heat and electricity needed by the building's users. One of possibilities to solve the problem is to use the $\mathrm{PV} / \mathrm{T}$ Photovoltaic Thermal systems, which combine both functions in one device, i.e. in a PV/T module.

It can be underlined that PV/T Photovoltaic Thermal technology can be used for new buildings, as well as for existing buildings, which can be suitably renovated, following energy sustainability measures. In order to reach nearly zero energy consumption, or nearly zero $\mathrm{CO}_{2}$ emissions targets of new buildings or buildings under thermal refurbishment and modernization, or going even further to reach the goal of PEDs - Positive Energy Districts [3], it is necessary to develop mechanisms to enhance development and implementation of solar systems characterized by the high fraction of solar energy supplied to thermal and electrical systems in buildings.

*Corresponding author: Dorota.Chwieduk@itc.pw.edu.pl 
PV/T Photovoltaic Thermal systems are believed to be such systems.

\section{$2 \mathrm{PV} / \mathrm{T}$ modules and systems}

$\mathrm{PV} / \mathrm{T}$ modules can work with different electrical and thermal efficiencies, and give different power and heat output. It depends on the ambient conditions in which they gain energy, mainly on solar irradiation and air temperature, and how the energy gained is used, from point of view of modes of operation of the system and distribution of energy needs in time.

With a decrease of solar irradiance the power of the PV cells and modules is reduced, caused by the decrease of the current (the voltage reduces only slightly). The power and efficiency of PV cells and modules decrease with the increase of their temperature. The temperature increase is caused by the absorbed solar radiation that is not converted into electricity, but is converted into heat (which is a consequence of the increase of internal energy). With the increase of the temperature of the PV cells the voltage is evidently decreasing (current is only slightly increasing) causing reduction of power and efficiency. This undesirable effect can be partially avoided by the heat extraction from the PV cells and modules through a fluid circulation along their bottom surfaces. Such solution is technically realized by the hybrid photovoltaic/thermal - PV/T module (collector) [3].

A PV/T module is the main element of the solar PV/T energy system, which provides electrical and thermal energy, thus achieving a higher energy conversion rate of the absorbed solar radiation, than both of such systems operating separately. The PV modules are coupled to heat extraction devices, in which air or water (or other liquid) of lower temperature than that of the PV modules is flowing through. As a result the cooling fluid is heated whilst the PV module temperature is reduced. In the case of air, the contact with the PV panels can be direct (flow over the surface). While for liquids, the contact is through a heat exchanger in a form of piping or channels in a plate. The thermal part of the PV/T modules, i.e. heat exchangers of the modules are usually connected to a water storage tank. When water is used as a cooling medium of the $\mathrm{PV} / \mathrm{T}$ modules it can circulate in an open loop between the PV/T modules and the storage tank. When antifreeze mixture circulates between $\mathrm{PV} / \mathrm{T}$ modules and the tank the loop is closed. Heat gained by the PV/T modules is stored in a tank and used when is needed. If temperature of the water stored in a tank is lower than required then an auxiliary heater is used.

Electric energy produced by $\mathrm{PV} / \mathrm{T}$ modules can be used through inverters directly by the electrical energy appliances installed at the building or transmitted to the grid. In a case of the on-grid system the grid is treated as a store. When there is an excess of energy gained by the $\mathrm{PV} / \mathrm{T}$ panels then this energy can be sent to the grid. An electrical system can also be equipped with batteries of different size depending on their function, e.g. they can be used as emergency store (for few hours breaks of electrical energy supplied to the building from the grid) or a few days store in a case of an off-grid system.

Combined PV/T systems with appropriate size of modules and energy storage should assure provision of the total energy needs: heating (DHW) and electricity of buildings in moderate climates in summer. These systems should operate in summer in monovalent mode using only one energy source -solar energy. However, there are some obstacles to reaching the goal of $100 \%$ solar energy fraction supplying thermal energy to a building in summer. Of course, knowing the level of solar energy availability in winter, it is obvious that solar systems need coupling to other energy systems to fulfill energy requirements. In $\mathrm{PV} / \mathrm{T}$ systems the production of electricity is the priority, therefore it is necessary to operate the PV modules at low temperature in order to keep the PV cell and the PV modules electrical efficiency at a sufficient level. This requirement limits the effective operation of the $\mathrm{PV} / \mathrm{T}$ thermal unit to low temperatures. Thus, the extracted heat can be not enough to supply all DHW heating needs in summer.

\section{PV/T systems for DHW heating and electricity production at the micro scale}

\subsection{Description of the PV/T system configuration and operation}

The paper presents an idea of application the PV/T Photovoltaic Thermal technology in moderate climates, (such as the Polish climate), at the micro scale, i.e. for a single family house. The paper analyses operation of the PV/T system applied to Domestic Hot Water - DHW heating and electricity production. The considered system is presented in Fig. 1.

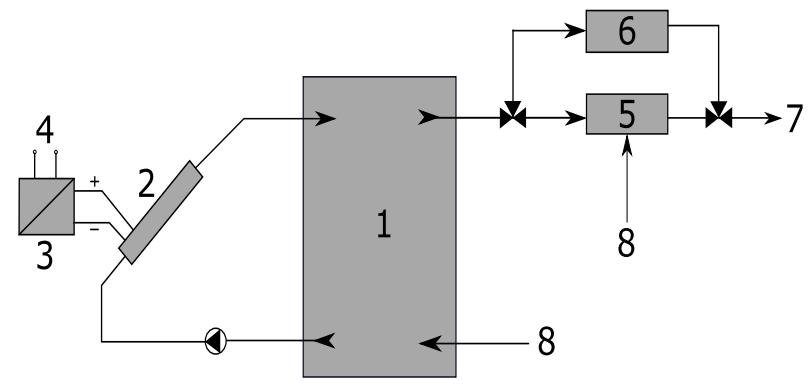

Fig. 1. PV/T system applied for Domestic Hot Water - DHW heating and electricity production

1 - storage tank, 2 - photovoltaic/thermal module, 3 - inverter

4 - electric energy consumption, 5 - mixer, 6 - auxiliary heater

7 - DHW consumption, 8 - filling with cold water from mains.

The thermal part of the PV/T system is a typical active solar water heating system used for DHW heating 
and working with an conventional auxiliary heater. This system is used to meet the demand of the owner. The collector loop is open. In a climate characterized by low ambient temperature, low solar irradiance and frequent overcast, as in Poland, it is recommended to use a close collector loop [4]. In such climatic conditions for all-year applications an antifreeze mixture (glycol-water) is applied and the collector loop and heat storage tank are separated by a heat exchanger. However, the preliminary analysis of the PV/T system operation showed that the thermal part of the system would not work in winter, due to small solar irradiation level and negligibly small amount of energy converted into thermal energy. As was mentioned, the priority is for electricity production in considered system. If the system is not used in winter for DHW then the water can circulate in a solar collector loop at the rest of the year, being a heat transfer and a heat storage medium at the same time.

Heat is stored in water, and storage is accomplished by using the thermal capacity of water. It is a short-term thermal storage system. Thermal stratification phenomena take place in the storage tank. It means, that the coldest water is located at the bottom and the temperature rises along with tank height, reaching maximum at its very top. The hot water outlet is located at the top part of the tank. The cold water inlet and outlet are at the bottom. The cold water outlet supplies cold water to $\mathrm{PV} / \mathrm{T}$ modules to cool them and the heat gained is transferred from the outlet of the modules to upper part of the water storage tank. Heat stratification is beneficial, because it allows user to choose an outlet nozzle position to meet the specific temperature heating needs. Full effectiveness of DHW heating is achieved if the temperature at the tank bottom does not fall below certain value and temperature difference between top and bottom layers is also maintained at the required level.

The thermal efficiency of a solar system depends on a number of individual factors related to the design and construction of $\mathrm{PV} / \mathrm{T}$ modules and the entire solar system, local insolation conditions, mode of operation of the solar system, and its method of its cooperation with storage and auxiliary or peak heating device/system. When solar radiation is available and the heat gained by the $\mathrm{PV} / \mathrm{T}$ modules is above the minimum value, the heat is stored in a storage tank. The following are the basic modes of supplying heat to the user: If there is a heat demand and the amount of heat and temperature of water stored in the tank is high enough then thermal energy is supplied directly from the tank to the user. If the amount of heat and the temperature of water stored in a tank are too low then the water from the tank flows through the auxiliary heater to be warm up to the required level. If the temperature of water in a storage tank is at the minimum level (usually it is $10^{\circ} \mathrm{C}$, which is equal to the water temperature of the supply network), then water from the supply network can flow directly to the auxiliary heater.
The PV/T system considered in the paper is an on-grid system without batteries. When PV/T modules operate the electrical energy produced is used directly or transmitted to the grid. The grid is used as a store of energy, where according to Polish regulations [5] the accumulation takes place with $80 \%$ efficiency. The considered $\mathrm{PV} / \mathrm{T}$ system is an on-grid system and because of that electricity can be taken from the grid all the time.

\subsection{Mathematical model of the system operation}

To analyze the solar energy availability for the surfaces of $\mathrm{PV} / \mathrm{T}$ modules of southern orientation and $30^{\circ}$ of inclination the solar irradiance has been calculated for given time using the isotropic solar radiation model of Liu-Jordan [6]. Thus, the solar irradiance $G_{s}$ on an inclined surface of the PV/T is given by:

$$
\begin{gathered}
G_{s}(t)=G_{b}(t) R_{b}(t)+G_{d}(t) R_{d}+ \\
+\left[G_{b}(t)+G_{d}(t)\right] R_{r} \rho
\end{gathered}
$$

where:

$G_{b}$ - direct solar irradiance on a horizontal surface in a given time, $\left(\mathrm{W} / \mathrm{m}^{2}\right)$;

$G_{d}$ - diffuse solar irradiance on a horizontal surface in a given time, $\left(\mathrm{W} / \mathrm{m}^{2}\right)$;

$R_{b}$ - correction factor for direct solar irradiance on an inclined surface in a given time;

$R_{d}$ - correction factor for diffuse solar irradiance on an inclined surface;

$R_{r}$ - correction factor for reflected solar irradiance on an inclined surface;

$\rho$ - reflectivity of the ground.

Direct and diffuse solar irradiance on a horizontal surface at a given time can be taken from a meteorological data base (e.g. [7]). Correction factors for diffuse and reflected solar irradiances are constant for given inclination and orientation of the surface under consideration. Reflectivity of the ground can be assumed as a constant. However, the correction factor for the direct solar irradiance on an inclined surface must be calculated for every moment of the considered time (usually for every hour) [6].

The useful heat rate $Q_{u}$ gained by the $\mathrm{PV} / \mathrm{T}$ module can be described by the Hottel-Whiller Bliss correlation [6]:

$$
\dot{Q}_{u}(t)=A_{P V T} F^{\prime}(t)\left[\begin{array}{c}
(\tau \alpha) G_{s}(t)+ \\
-U_{L}(t)\left(\bar{T}_{f}(t)-T_{a}(t)\right)
\end{array}\right]
$$

where:

$A_{P V T}$ - area of PV/T $\left(\mathrm{m}^{2}\right)$

$(\tau \alpha)$ - transmittance - absorptance product of the thermal part (just heat exchanger) of the PV/T module;

$F^{\prime}$ - PV/T module efficiency factor;

$G_{s}$ - solar irradiance on inclined module plane determined by equation $(1),\left(\mathrm{W} / \mathrm{m}^{2}\right)$; 
$U_{L}$ - thermal loss coefficient $\left(\mathrm{W} / \mathrm{m}^{2} \mathrm{~K}\right)$;

$T_{f}$ - arithmetic average of fluid inlet and outlet temperature $(\mathrm{K})$;

$T_{a}$ - ambient air temperature $(\mathrm{K})$.

The thermal efficiency of the $\mathrm{PV} / \mathrm{T}$ module is expressed as ratio of the useful heat rate (given by equation (2)) to the incident solar irradiance (determined by equation (1)) for a given surface area of the PV/T modules.

As mentioned, the heat rate $Q_{u}$ gained by the $\mathrm{PV} / \mathrm{T}$ module is stored in a storage tank. The tank has been modelled as a tank with thermal stratification and has been divided into $n$ layers. Numbering of layers goes from the top to the bottom. The energy balance for the $i$ layer can be written as:

$$
\begin{aligned}
& \left(\rho c_{w} V_{i}\right) \frac{d T_{S, i}}{d t}=\dot{Q}_{u}(t)-\dot{Q}_{H W}(t)-\dot{Q}_{L}(t)+ \\
& +\dot{Q}_{S, i-1}(t)-\dot{Q}_{S, i+1}(t)
\end{aligned}
$$

where:

$\rho$ - density of water of layer $i,\left[\mathrm{~kg} / \mathrm{m}^{3}\right]$,

$c_{w}$ - specific heat of water of layer $i,[\mathrm{~J} /(\mathrm{kg} \mathrm{K})]$,

$V_{i}$ - volume of water of layer $i,\left[\mathrm{~m}^{3}\right]$,

$T_{s, \mathrm{i}}$ - temperature of water of layer $i,[\mathrm{~K}]$,

$t$ - time, [s],

$Q_{u}$ - useful heat rate gained by the PV/T module and supplied to the layer $i$, [W],

$Q_{H W}$ - heat rate supplied to the user flowing out of the layer $i,[\mathrm{~W}]$,

$Q_{L}$ - heat rate losses of the layer $i,[\mathrm{~W}]$,

$Q_{S, i-1}$ - heat rate transfer between layer $i$ and layer $i-1$ above, [W],

$Q_{S, i+1}$ - heat rate transfer between layer $i$ and layer $i+1$ below, [W].

To solve the problem the model of the end use pattern of DHW has to be assumed. The time step for the end use of water is usually equal to one hour. Extracting heat out of the store at the top to supply heat for the end use keeps the stratification effect. This is beneficial for supplying the coldest water from the bottom of the tank to the PV/T module to extract heat during its operation. When the energy balance equations are formulated for every layer of the tank then control functions are defined: a PV/T module control function to determine which layer receives warm water from the module, and a load return control function for the liquid returning from the load [6]. To solve the governing equations a numerical simulation was applied on a base of a purpose-written numerical code formulated in Visual Basic [8]. The daily distribution of hot water consumption hour by hour was assumed [9]. The distribution assumed is not the best one for solar energy heating systems, because there is no use of hot water during the day time for 6 hours. Solar irradiation was calculated using equation (1) and as an input averaged hourly solar radiation data on horizontal surface for averaged days of averaged months of the year [6] for Warsaw.
Electric power output of the PV/T module can be described by a standard formula:

$$
P(t)=V_{e l}(t) I_{e l}(t)
$$

In case of the $\mathrm{PV} / \mathrm{T}$ modules, as in regular $\mathrm{PV}$ modules, the efficiency is changing, even very rapidly in time. According to the standard definition of efficiency the electric efficiency of the PV/T module is expressed as ratio of the electric power output (given by equation (2)) to the energy rate input, i.e. incident solar irradiance for a given surface area of the PV/T modules. As already mentioned the electrical efficiency of the PV and as a result of the PV/T strongly depends on solar irradiance, ambient air temperature and the module temperature. Therefore, very often the electrical efficiency of a PV module is determined as a function of all of them. The same situation applied to determination of the electrical efficiency of the PV/T module. There are different formulae in the literature to determine the PV module temperature under different operation conditions [10] [14]. However, up to now there is no universal formula recommended for analysis of the efficiency of the PV system operating in different conditions. What is more there is no formula for the temperature of a PV module $\left(T_{P V}\right)$ being a part of a $\mathrm{PV} / \mathrm{T}$ module. One study [8] performed, among others, was aimed at giving some input for determination of those formulas.

One of the formula to determine the electrical efficiency of the PV module, which can be used for the PV/T module is following [10]:

$$
\eta_{e l}(t)=(\tau \alpha)(t) \eta_{r e f}\left(1-\beta_{r e f}\left(T_{P V}(t)-T_{r e f}\right)\right)
$$

where:

$(\tau \alpha)$ - transmittance - absorptance product;

$\eta_{\text {ref }}$ - efficiency of the PV module in the STC (Standard Test Conditions);

$\beta_{\text {ref }}$-temperature efficiency factor, $[1 / \mathrm{K}]$;

$T_{\text {ref }}$ - temperature of the PV module in the STC (Standard Test Conditions) equal to $25^{\circ} \mathrm{C}$.

In a specific $\mathrm{PV} / \mathrm{T}$ module the $\mathrm{PV}$ module must have the transmittance - absorptance product, the efficiency of the PV module, the temperature efficiency factor and the reference temperature of the PV determined for the STC Standard Test Conditions. These parameters should be given by the PV producers. The temperature of the PV module $\left(T_{P V}\right)$ should be determined. It is changing in time and depends on parameters of the system operation. This temperature is different in a standard PV module and in a $\mathrm{PV} / \mathrm{T}$ module.

The temperature of the PV module $\left(T_{P V}\right)$ is usually described by different approximation formulas, which take into account the solar irradiance and ambient air temperature. Some of them refer to NOCT - Nominal Operating Cell Temperature Conditions. It is difficult to find a correlation, which determines the temperature of 
the $\mathrm{PV}$ in the PV/T module. As has been described, in such a situation the temperature of the PV module depends not only on solar radiation and ambient air conditions, but also on heat transfer conditions between the PV module and fluid circulating in a heat exchanger in the PV/T module.

Tripanagnostopoulos [10] proposed to call the temperature of the $\mathrm{PV}$ in the $\mathrm{PV} / \mathrm{T}$ module as $\left(T_{P V}\right)_{\text {eff. }}$ To determine this temperature he suggested to use Lasnier and Ang formula [15] for the regular PV module temperature and correct it through introduction of the temperature difference between the $T_{f}$ arithmetic average of the fluid inlet and outlet temperature at the PV/T module and the ambient air $T_{a}$ temperature. Thus, to calculate the electrical efficiency of the PV/T module it is necessary to use in equation (5) instead the value of the $T_{P V}$ temperature the value of $\left(T_{P V}\right)_{\text {eff, }}$ which can be expressed as follows:

$$
\begin{gathered}
\left(T_{P V}\right)_{e f f}(t)=30+0.0175\left(G_{s}(t)-300\right)+ \\
+1.14\left(T_{a}(t)-25\right)+\left(T_{f}(t)-T_{a}(t)\right)
\end{gathered}
$$

The daily distribution of electricity consumption hour by hour was assumed [16]. The distribution assumed is similar to that of DHW consumption, assuming that for 6 hours during the day time electricity consumption is very small (only stand-by mode of electrical appliances is used). Such a situation is not good for solar energy utilization, because the solar energy availability and electrical energy use are not coherent in time. It means that during the day time, energy produced by the PV/T modules will be send to the grid and electricity from the grid will be used when there is no solar radiation or its level is low.

\subsection{Results of simulation studies}

Some selected results of numerical simulation of the $\mathrm{PV} / \mathrm{T}$ system operation at a micro scale in Polish climatic conditions are presented in this section. Simulation studies have been performed for different sizes of the $\mathrm{PV} / \mathrm{T}$ system used to supply heating energy for the DHW system and electric energy for lighting and other electrical appliances. Daily consumption of heating energy for the DHW system is about $8.15 \mathrm{kWh}$ and electricity about $8.22 \mathrm{kWh}$. As mentioned, daily distribution of energy consumption changes during the day time, but states the same for every day of the year. The maximum energy consumption is in the evening from 5 p.m. to 11 p.m. and in the morning from 7 a.m. to 9 a.m., but at that time is much smaller.

The PV/T system selected for presentation in the paper seems to be the most suitable for electrical energy consumption of the building. There are PV/T modules of $A_{P V}$ area equal to $22.2 \mathrm{~m}^{2}$ with installed capacity of $3 \mathrm{~kW}_{\mathrm{p}}$. They are located on a south roof inclined at $30^{\circ}$. The volume of the water storage tank is $1.11 \mathrm{~m}^{3}$ (height
$2.34 \mathrm{~m}$, diameter $0.78 \mathrm{~m}$ ). Two types of the PV/T modules have been analyzed: with a glazed cover and without.

Figures 2 and 3 present the daily distribution of hourly averaged thermal efficiency of the PV/T modules without cover and with one cover, respectively. As could be expected, the glazed (one cover) PV/T modules are characterized by much higher thermal efficiency than the unglazed. The highest thermal efficiency is in summer and can reach $15 \%$ in the case of unglazed modules and nearly $24 \%$ in the case of glazed modules. In winter for three months: December - February the unglazed modules do not work and in November for very short time, about 2 hours, with low efficiency (maximum 5\%). The glazed PV/T modules do not operate in December and in January only for about 1 hour (maximum efficiency 5\%). However, results present in Fig. 4 and 5 show the opposite situation in the case of the daily distribution of electrical efficiency of the considered $\mathrm{PV} / \mathrm{T}$ modules. Electrical efficiency is the highest in winter and the lowest in summer. In a case of PV/T modules without covers the highest electrical efficiency is in winter in the morning and reaches $12.2 \%$, in a case of modules with a cover it reaches $11.2 \%$. In summer minimal electric efficiency is about 2 p.m. and for the $\mathrm{PV} / \mathrm{T}$ modules without cover it can drop to $10.1 \%$ and for modules with a cover even much more to $8 \%$. It is evident, that the cover is a good solution for improving thermal efficiency of the PV/T module but it cannot be recommended for the efficient operation of the PV part of the module.

\section{Conclusions}

Simulation studies performed show that PV/T systems with modules without a cover can operate with relatively high electrical efficiency during the whole year, and especially in winter, in micro systems supplying heating energy for a DHW system and electricity in moderate climates. Systems with glazed modules have lower electrical efficiencies, especially in summer. As has been already mentioned the opposite situation can be noticed from the point of view of thermal efficiency, which is larger for the glazed modules. As simulation studies showed, changes of the share of solar energy in supplying energy needs annually have the same tendency (these results are not presented in the paper, but can be found in literature [8]). For the considered size of the $\mathrm{PV} / \mathrm{T}$ systems and energy needs the modules with glazing can fully cover the DHW demand during 5 months, from May to the end-of September, but they cannot cover the electricity demand, which can be at level of $67 \%$ in September to $93 \%$ in June. At the same time the modules without glazing can cover the heating demand only from $62 \%$ in September to $90 \%$ in July, but they can cover all the electricity demand from May till the end of August (using the grid as storage). What is more, during all these 
four months there is surplus of energy sent to the grid, which (according to existing regulations including net

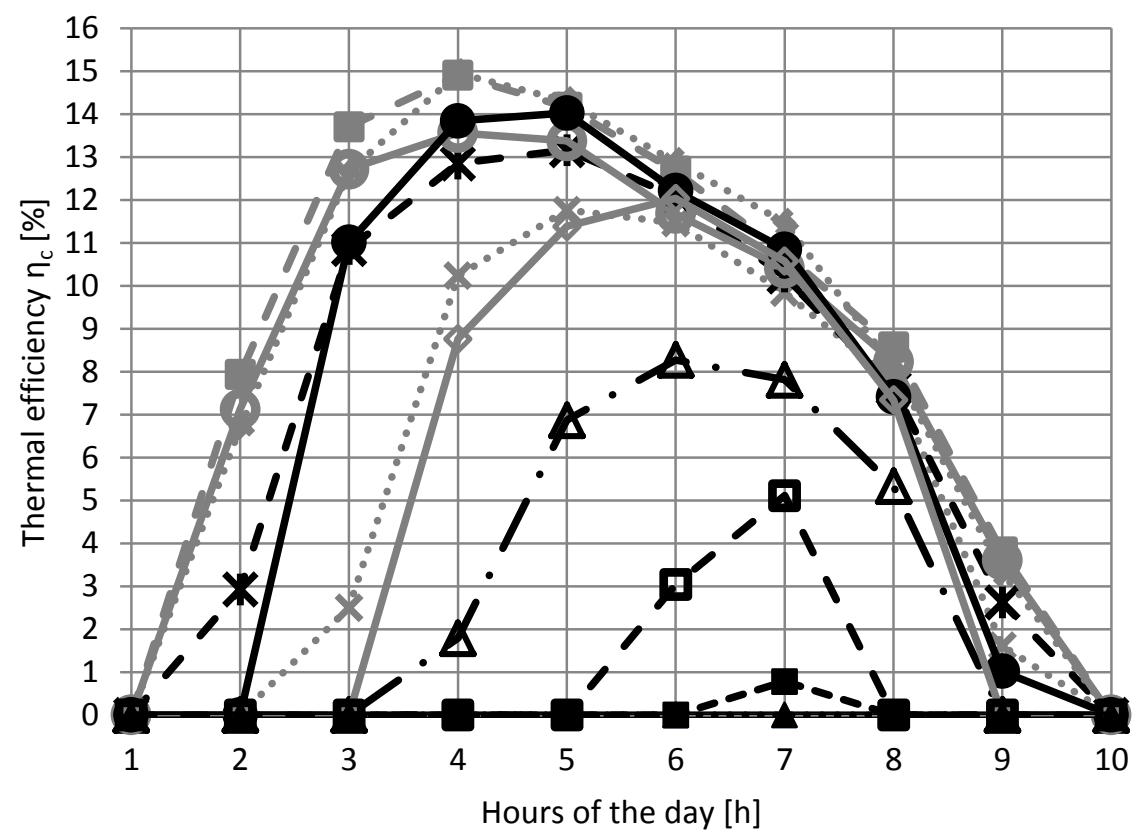

metering) can be taken out of the grid later e.g. in winter months.

Fig. 2. Daily distribution of hourly averaged thermal efficiency of the PV/T modules without cover.
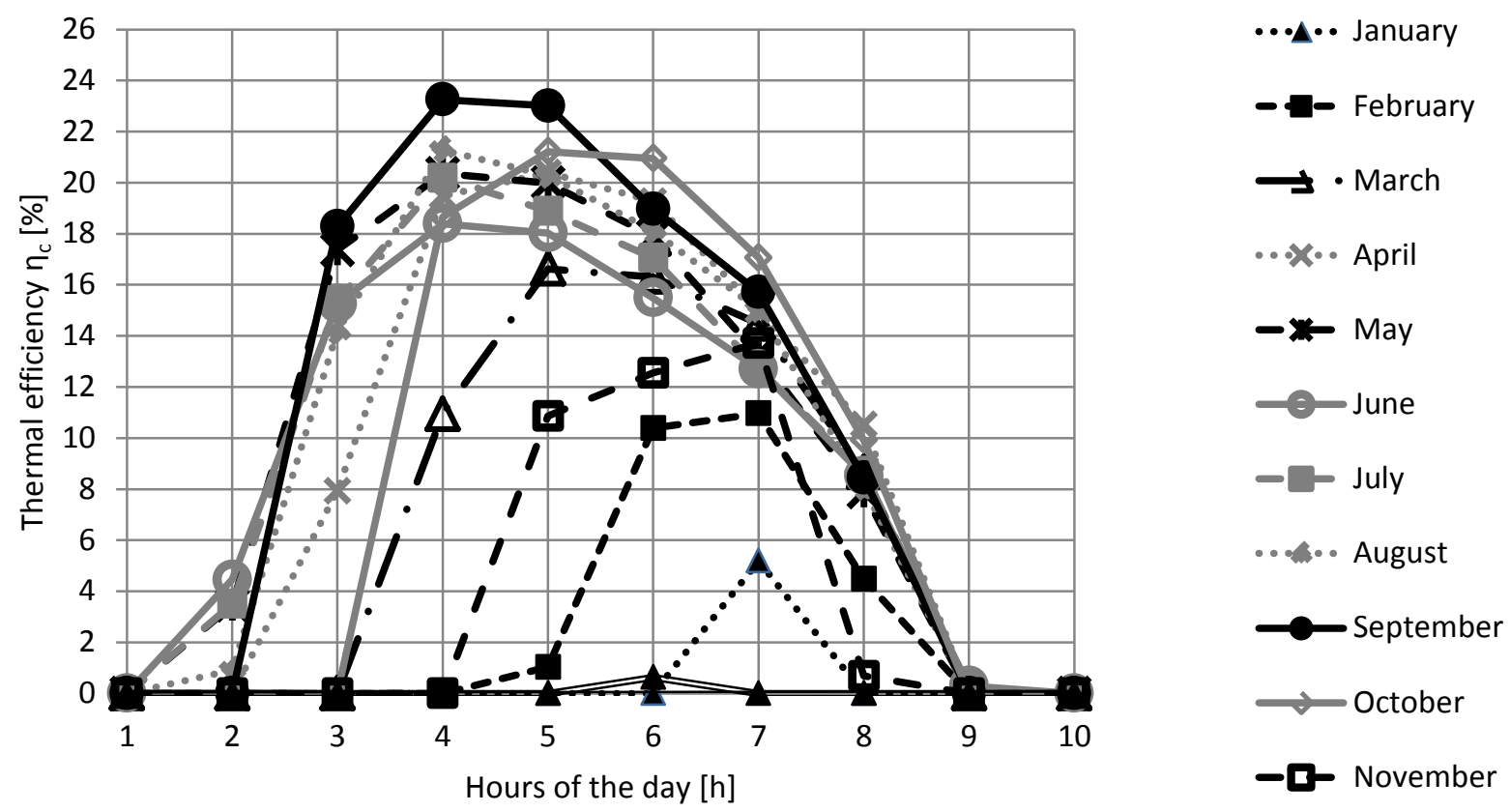

Fig. 3. Daily distribution of hourly averaged thermal efficiency of the PV/T modules with a cover. 

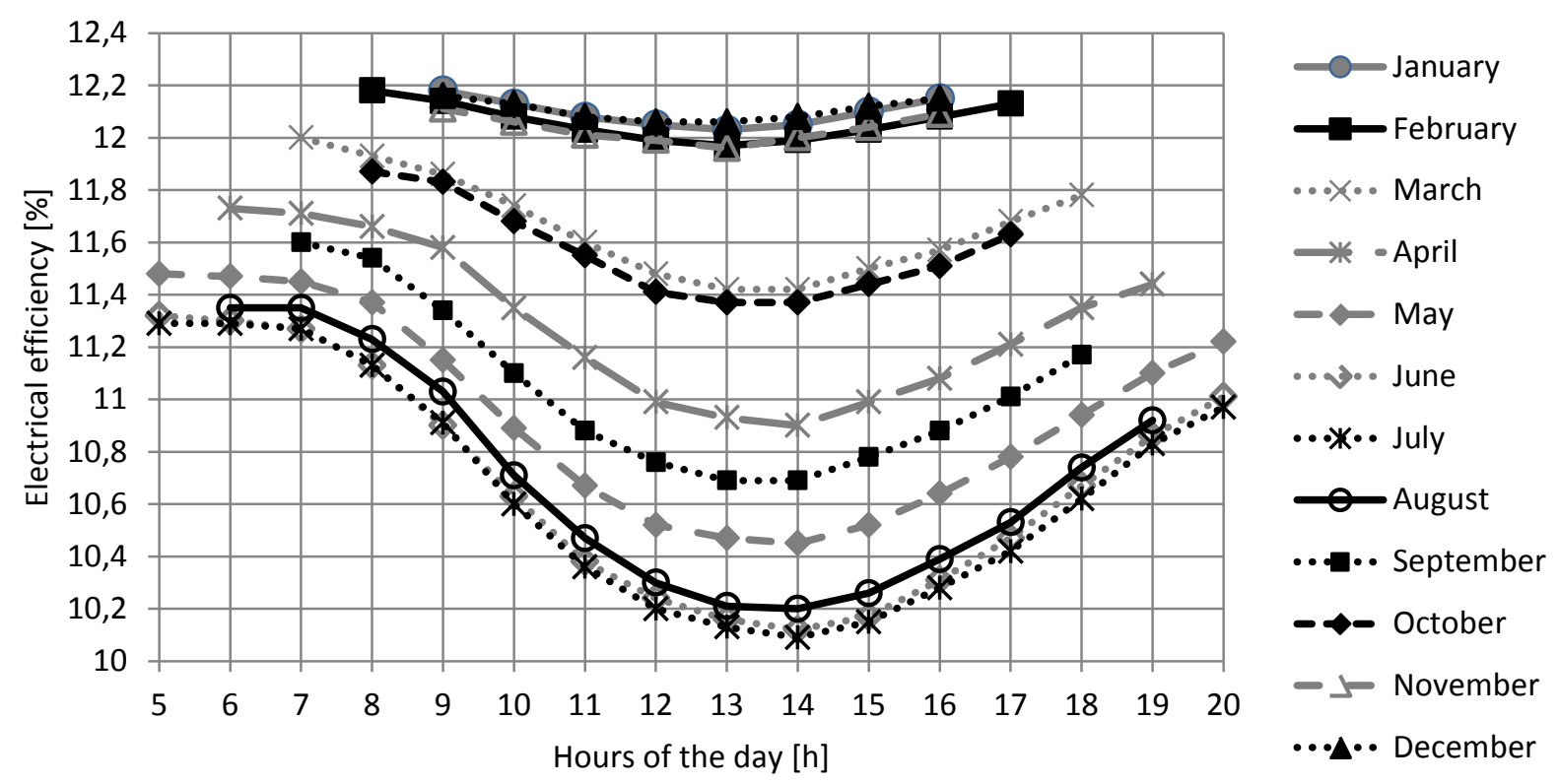

Fig. 4. Daily distribution of hourly averaged electrical efficiency of the PV/T modules without a cover.
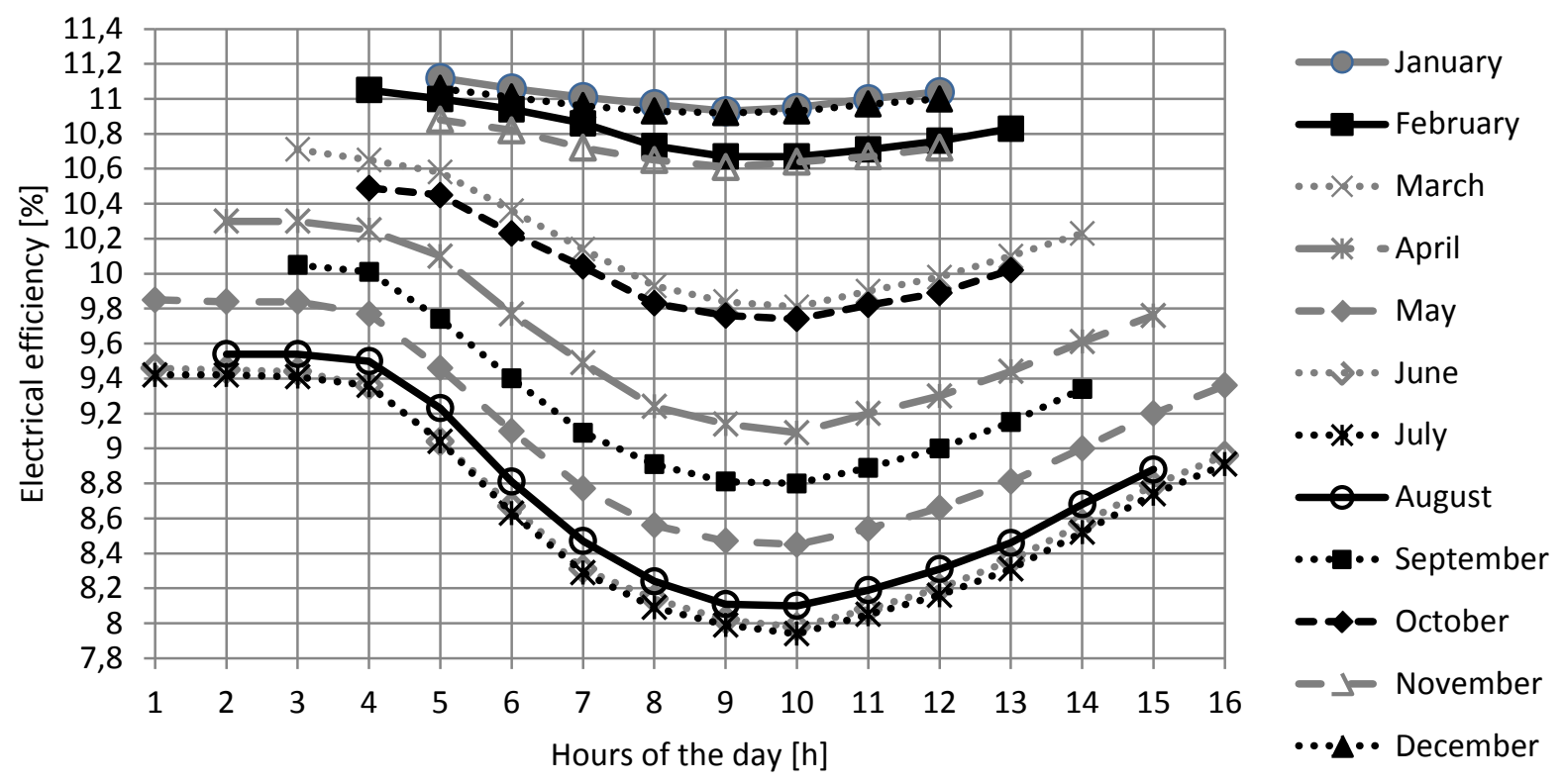

Fig. 5. Daily distribution of hourly averaged electrical efficiency of the PV/T modules with a cover.

All this shows that micro $\mathrm{PV} / \mathrm{T}$ systems can be recommended for moderate climates. Because of their electrical efficiency perhaps it is better to use the PV/T modules without covers. In such a case they do not operate in winter as thermal modules, so without danger of freezing the water can be used as working fluid for the rest of the year. However, if more heat could have been extracted in summer from the modules, because of much larger heating needs (e.g. swimming pools, underground thermal energy storage), then also the electrical efficiency would not drop so much. It can be stated that the $\mathrm{PV} / \mathrm{T}$ technology can assure more effective operation of the PV modules if they are cooled during their operation, which in a moderate climate is mainly needed in summer and spring. There are many questions to be answered. The PV/T technology is a new one and it is very difficult to formulate the final recommendation. Much more theoretical and experimental research is needed, including optimization studies.

Building-integrated photovoltaic/thermal systems (BIPV/T) should become popular in buildings in moderate climates. They can be integrated with building envelope, primarily its main façade and roof on the southern side. They can be treated as a kind of a building 
envelope ("construction") element, electricity generator (device which simultaneously generate electricity) and heating device. Depending on energy consumption of the building and taking into account the pattern of the heating energy use, part of the envelope can be constructed as the BIPV/T and a part just as the BIST Building Integrated Solar Thermal System.

\section{References}

1. Directive 2010/31/EU of the European Parliament and of the Council of 19 May 2010 on the energy performance of buildings.

2. E. Biyik, M. Araz, A. Hepbasli, et al., A key review of building integrated photovoltaic (BIPV) systems, Engineering Science and Technology, an International Journal, Vol. 20, 833-858, (2017).

3. A. Monti \& Pesch, Dirk \& Ellis, Keith \& Mancarella, Pierluigi: Energy Positive Neighborhoods and Smart Energy Districts: Methods, Tools, and Experiences from the Field, (2016).

4. D. Chwieduk, Energetyka słoneczna budynku, Wydawnictwo Arkady, Warszawa, (2011).

5. Act on Renewable Energy Sources ("RES Act", Dz.U. 2015 poz. 478)

6. J.A. Duffie, W.A. Beckman, Solar Engineering of Thermal Processes, Wiley, (2013).

7. Official website of the Ministry of Investment and Development, Typical meteorological and statistical climate data, https://www.miir.gov.pl (access: 13/07/2018).

8. J. Bigorajski, D. Chwieduk (in press), Analysis of a micro photovoltaic/thermal - PV/T system operation in moderate climate, Renewable Energy, DOI: 10.1016/j.renene.2018.01.116, (2018).
9. E. Fuentes, L. Arce, J. Salom, A review of domestic hot water consumption profiles for application in systems and buildings energy performance analysis, Renewable and Sustainable Energy Reviews, Vol. 81, 1530-1547, (2018).

10. T.M. Pavlović, Y. Tripanagnostopoulos, et al., Solar Energy in Serbia, Greece and the Republic of Srpska, Academy of Sciences and Arts of the Republic of Srpska, Department of NaturalMathematical and Technical Sciences Monograph, Vol. XXVI, Banja Luka, (2015).

11. E. Skoplaki, A.G. Boudouvis, J.A. Palyvos, A simple correlation for the operating temperature of photovoltaic modules of arbitrary mounting, Solar Energy Materials \& Solar Cells, Vol. 92, 1393-1402, (2008)

12. E. Skoplaki, J.A. Palyvos, On the temperature dependence of photovoltaic module electrical performance: A review of efficiency/power correlations, Solar Energy, Vol. 83, 614-624, (2009).

13. E. Skoplaki, J.A. Palyvos, Operating temperature of photovoltaic modules: A survey of pertinent correlations, Renewable Energy, Vol. 34, 23-29, (2009)

14. Y. Tripanagnostopoulos, Photovoltaic/Thermal Solar Collectors [in:] Comprehensive Renewable Energy, Newnes, t. 3, 255-300, (2012).

15. F. Lasnier, T.G. Ang, Photovoltaic Engineering Handbook, Princeton, NJ: Adam Higler, (1990).

16. B. Anderson, S. Lin, A. Newing, et al.: Electricity consumption and household characteristics: Implications for census-taking in a smart metered future, Computers, Environment and Urban Systems, Vol. 63, 58-67, (2017). 